\title{
Dissecting lipid accumulation of microalgae Nannochloropsis oculata using fluorescent image analysis
}

\author{
Trinh Cam Tu, Tran Thanh Huong, Bui Trang Viet
}

\begin{abstract}
Cell suspension of Nannochloropsis oculata was cultured in a modified $\mathbf{f} / 2$ medium to study the changes of lipid content during phases of growth. The growth of cell suspension was determined by measuring the cell density and diameter under light microscope. To observe and evaluate the accumulation of lipid droplets in microalgae cells, lipid droplets were stained with Nile Red fluorescent dye then examined under fluorescence microscope and the obtained images were analyzed using Fiji ImageJ, an image processing program. The cell density increased quickly at the first 6 days of culture while cell diameter reached the highest value at the $8^{\text {th }}$ day and $20^{\text {th }}$ day of culture. The presence of lipid droplets in the cells could be observed from the 20th day of culture. The size of lipid droplets was gradually increased after 60 days. Treatment of depleted nitrogen for 4 days resulted an increase in the accumulation of lipid. The intracellular lipid accumulation during phases of growth of the cell suspension under nitrogen-depleted conditions was also discussed.
\end{abstract}

Keywords - Fiji ImageJ, lipid, microalgae culture, Nannochloropsis oculata

\section{INTRODUCTION}

$\mathrm{S}$ torage lipids in microalgae is a potential source of biodiesel, an alternative energy replaces fossil fuels [1-3]. Fluorescence microscope, Nile Red dye, and ImageJ software were used to observe and evaluate the shape, size, and density of some intracellular pigments or lipid droplets in microalgae [4-10]. The experimental results showed that the lipid yield was enhanced in nitrogen-depleted condition in comparison to

Received: 12-9-2017, accepted 20-01-2018, published 2011-2018

Trinh Cam Tu, Tran Thanh Huong, Bui Trang Viet University of Science, $V N U-H C M$

*Email: trthuong@hcmus.edu.vn nitrogen rich condition [11]. In this study, we used ImageJ software to analyze the fluorescent images of Nannochloropsis oculata cells stained by Nile Red. The lipid accumulation of microalgae cells during phases of growth under nitrogen sufficient and nitrogen-depleted conditions was also analyzed.

\section{MATERIALS AND METHODS}

Microalgae Nannochloropsis oculata was cultured in Erlenmeyer flask with $20 \mathrm{~mL}$ of a modified f/2 medium of Chiu et al. (2009) [12]. In this modified $\mathrm{f} / 2$ medium, triple concentrations of macro-elements and micro-elements were used, and artificial sea water was used instead of natural sea water. The artificial sea water has the following composition (per liter): $29.23 \mathrm{~g} \mathrm{NaCl}$, $1.105 \mathrm{~g} \mathrm{KCl}, 11.09 \mathrm{~g} \mathrm{MgSO}_{4} .7 \mathrm{H}_{2} \mathrm{O}, 1.21 \mathrm{~g}$ Trisbase, $1.83 \mathrm{~g} \mathrm{CaCl}_{2} .2 \mathrm{H}_{2} \mathrm{O}$, and $0.25 \mathrm{~g} \mathrm{NaHCO}_{3}$.

Cell suspensions culture of Nannochloropsis oculata

Cell suspensions of Nannochloropsis oculata at the day 6 of culture were transfered to Erlenmeyer flasks containing $20 \mathrm{~mL}$ of modified $\mathrm{f} / 2$ medium. At the beginning of culture, the cell density was 106 cells $/ \mathrm{mL}$ and the cell diameter was about 3.14 $\pm 0.06 \mu \mathrm{m}$. The growth conditions were: 12 hours' light/dark cycle, $2800 \pm 200$ lux, and $28 \pm 2{ }^{\circ} \mathrm{C}$. The cultures were rotated at 75 round per minute (RPM) (GFL 3019 shaker, Germany).

Effects of nitrogen-depleted condition in growth and lipid accumulation of Nannochloropsis oculata

Microalgae cell suspensions at the day 6 were cultured in Erlenmeyer containing modified $\mathrm{f} / 2$ medium without nitrogen for 2, 4, or 6 days. After that, the packed cell volume (PCV) of cell suspensions was collected by centrifugation at 2000 RPM in 15 minutes, at $4{ }^{\circ} \mathrm{C}$ and the harvested 
cells were then transferred to modified $\mathrm{f} / 2$ medium. The results were then compared to the one of the control, the cell suspension was cultured for 10 days in modified $\mathrm{f} / 2$ with $0.88 \mathrm{M}$ nitrogen. The cell density, cell diameter and lipid accumulation were evaluated after the treatments and 10 days of culture in modified $\mathrm{f} / 2$ medium with and without nitrogen.

\section{Measurements of cell density and diameter}

The cell density of Nannochloropsis oculata was measured by counting the total number of cells and clusters in hemocytometer under light microscope (Kruss, MBL 2000) [13]. A drop of 5 $\mu \mathrm{L}$ of cell suspension was placed in Neubauer Improved chamber (Assistent, Germany). The chamber was observed under light microscope at $400 \mathrm{X}$ to count the total number of cells and clusters. The measurement was carried out in triplicate with 3 sample/time. Cell diameter was measured by using an eyepiece micrometer under light microscope. The measurement was conducted 10 times with 10 cells or/ and clusters/time.

\section{Evaluation of lipid droplets in microalgae cell using Nile Red staining}

Nile Red was dissolved in dimethylsulphoxide (DMSO) at a concentration of $0.5 \mathrm{mg} / \mathrm{mL}$ and stored in dark at $4{ }^{\circ} \mathrm{C}$. A volume of $20 \mu \mathrm{L}$ of Nile Red solution was added to $100 \mu \mathrm{L}$ of microalgae cell suspension and incubated in darkness for 15 minutes at room temperature. Fluorescence was observed under fluorescent microscope (Olympus CKX41, objective lens 40X, ocular lens 16X). The experiments were repeated 3 times with 3 samples/time.

\section{Fluorescence microscopy}

Fluorescence microscope (Olympus CKX41) was used to observe Nile Red fluorescence. Yellow fluorescence of Nile Red was viewed under the excitation of light with 460-480 nm wavelength and the emission of light with 530-580 $\mathrm{nm}$ wavelength. The images of stained cells were taken at the $30^{\text {th }}$ seconds of light exposure using Leica camera (DFC450).

\section{Picture analysis by Fiji ImageJ software}

Pictures of fluorescence were analyzed by Fiji ImageJ software, version $1.50 \mathrm{e}$ for Macintosh, with Analyze Particles function. In this method, we used some defines to clarify fluorescence such as [4]:

Number of cells was counted in the images which was taken under normal light. Number of fluorescent cells was counted in the images which was taken under excitation and emission light.

Fluorescent region was the yellow region under excitation of 460-480 $\mathrm{nm}$ and a fluorescent region is equal to an intracellular lipid droplet. Fluorescent regions whose areas were less than 10 square pixels were considered non-significant therefore be eliminated. The cell could show no or negligible fluorescent regions.

Area and Integrated Density were the two indexes of Fiji ImageJ. In that, Area index corresponded to the size of the fluorescence region of lipid droplets and the Unit of Area was square pixel. One $\mu^{2}$ equaled to 17.4 square pixel. Total area $\left(\mu \mathrm{m}^{2}\right)$ was the sum of all areas of all fluorescent regions. Integrated Density was changed from 0 to 255 . This index represented the brightness of fluorescent region. Total integrated density was sum of integrated densities of all fluorescent regions.

\section{Statistical analysis}

Results in all experiments were tested with Duncan's test at significant level 0.05 using IBM SPSS Statistic version 20.0 for Macintosh. Data in tables were shown as mean $\pm \mathrm{SE}$ (standard error) following by different alphabets which were expressed the differences in statistical analysis.

\section{RESULTS AND DISCUSSION}

\section{Fluorescence of lipid droplets staining by Nile Red}

Lipid droplets showed yellow fluorescence with Nile Red dye under the excitation wavelength of 460-480 nm (Fig. 3). The number of fluorescent regions corresponded to the number of lipid droplets in the cells. The size of lipid droplet was featured by the area of fluorescent regions.

In the sample, the cell suspension at the day $20^{\text {th }}$ of culture was used to evaluate the intracellular lipid droplets by analyzing the fluorescence images of Nile Red stained cells using Fiji ImageJ. In the images which had taken under normal light, there were 15 microalgae cells while in the images which had taken under excitation light, there were 5 fluorescent cells. Fig. 1 showed the result exported from Fiji ImageJ. 


\section{CHUYÊN SAN KHOA HỌC TỬ NHIÊN, TậP 2, SỐ 5, 2018}

\begin{tabular}{l|l|l}
\multicolumn{3}{l}{0} \\
\hline & Area & IntDen \\
\hline 1 & 257 & 9932 \\
2 & 614 & 32081 \\
3 & 7 & 313 \\
4 & 1 & 36 \\
5 & 1 & 50 \\
6 & 1 & 30 \\
7 & 17 & 534 \\
8 & 1 & 24 \\
9 & 69 & 2475 \\
10 & 1 & 30 \\
11 & 4 & 148 \\
12 & 1 & 30 \\
13 & 180 & 6679 \\
14 & 453 & 21204 \\
15 & 4 & 95 \\
16 & 1 & 20 \\
17 & 1 & 30 \\
18 & 1 & 24 \\
19 & 2 & 79 \\
20 & 4 & 159 \\
21 & 71 & 2317 \\
22 & 973 & 42410 \\
& &
\end{tabular}

Fig. 1. Result exported from the Fiji ImageJ when using Analyzing Particles function for fluorescent images

- Column 1 was the number of fluorescent regions. There were 22 fluorescent regions which were numbered from 1 to 22 .

- Column 2 (Area) was the area of fluorescent regions in the column 1. Among 22 fluorescent regions in the column 1,14 fluorescent regions which were numbered $3,4,5,6,8,10,11,12,15$, $16,17,18,19$, and 20, had the areas less than 10 square pixels. These fluorescent regions were therefore be eliminated. The real number of fluorescent regions was 8 . They were $1,2,7,9,13$,
14,21 , and 22. The total area in the image was the sum of 8 areas of 8 fluorescent regions.

- Column 3 (IntDen) was integrated the density of fluorescent region in the column 1. The total integrated density in the image was the sum of 8 integrated densities of 8 fluorescent regions.

- The number of fluorescent region in a fluorescent cell was the ratio of number of fluorescent regions and number of fluorescent cells.

- The total area in a fluorescent cell was the ratio of total areas and number of fluorescent cells.

\section{Growth of cell suspension of Nannochloropsis} oculata cultured in modified $\mathbf{f} / \mathbf{2}$ medium

The cell density increased rapidly in the first 6 days of culture. From the $6^{\text {th }}$ day to the $8^{\text {th }}$ day, the cell density was steady and slightly increased again from the $8^{\text {th }}$ day to the $20^{\text {th }}$ day.

The cell diameter progressively increased during growth. At the $8^{\text {th }}$ day and the $20^{\text {th }}$ day, the cells had their widest diameter (Fig. 2).

During the growth, the percentage of small cells increased while percentage of large cells decreased. The cell suspension showed a highest percentage of small cells and lowest percentage of large cells at the $2^{\text {nd }}$ day and the $12^{\text {th }}$ day (Table 1 ).

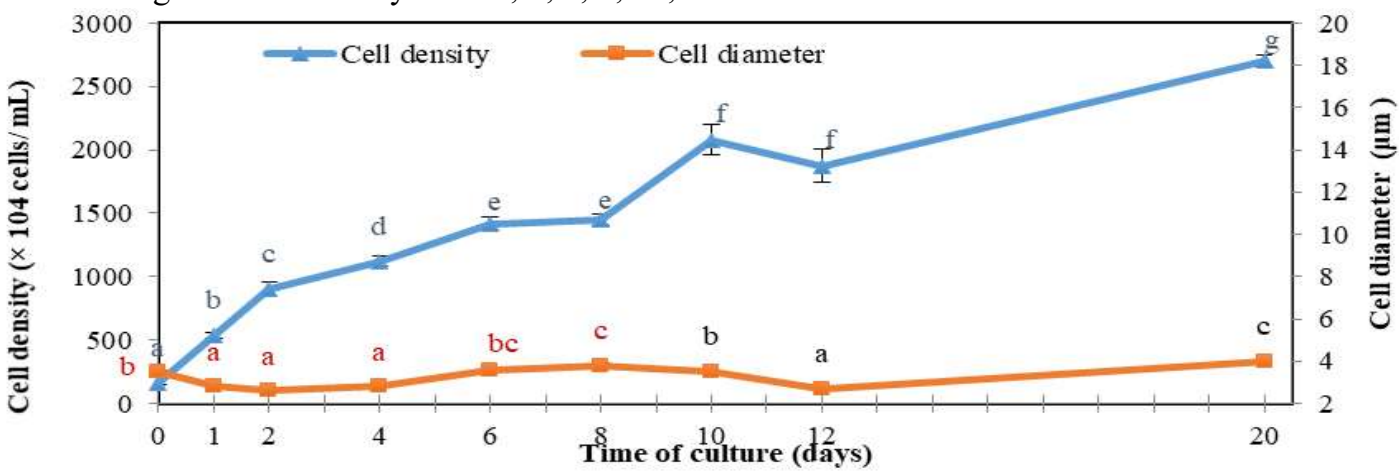

Fig. 2. Changes of cell density $\left(\times 10^{4}\right.$ cells $\left./ \mathrm{mL}\right)$ and cell diameter $(\mu \mathrm{m})$ of microalgae suspension cultured in modified $\mathrm{f} / 2 \mathrm{medium}$. The different alphabets above values in the same line express differences in statistical analysis according to Duncan's test $(p \leq 0.05)$ Table 1. Percentage of cell size of Nannochloropsis oculata cultured in Erlenmeyer flasks containing $20 \mathrm{~mL}$ modified f/2 medium.

\begin{tabular}{cccc}
\hline Time of culture (days) & $\begin{array}{c}\text { \% small cell } \\
(\leq 2.56 \mu \mathrm{m})\end{array}$ & $\begin{array}{c}\text { \% medium cell } \\
(2.56-3.84 \mu \mathrm{m})\end{array}$ & $\begin{array}{c}\text { \% large cell } \\
(\geq 3.84 \mu \mathrm{m})\end{array}$ \\
\hline 0 & $25.74 \pm 2.2^{\mathrm{b}}$ & $10.89 \pm 2.7^{\mathrm{a}}$ & $63.37 \pm 1.7^{\mathrm{a}}$ \\
1 & $62.38 \pm 3.9^{\mathrm{c}}$ & $23.76 \pm 2.2^{\mathrm{b}}$ & $13.86 \pm 1.6^{\mathrm{b}}$ \\
2 & $85.15 \pm 5.1^{\mathrm{d}}$ & $11.88 \pm 3.8^{\mathrm{a}}$ & $2.97 \pm 1.2^{\mathrm{a}}$ \\
4 & $59.41 \pm 2.0^{\mathrm{c}}$ & $29.70 \pm 4.7^{\mathrm{b}}$ & $10.89 \pm 4.3^{\mathrm{b}}$ \\
6 & $17.82 \pm 3.3^{\mathrm{a}}$ & $17.82 \pm 5.1^{\mathrm{a}}$ & $64.36 \pm 7.6^{\mathrm{c}}$ \\
8 & $17.82 \pm 3.3^{\mathrm{a}}$ & $9.90 \pm 3.9^{\mathrm{a}}$ & $72.28 \pm 6.3^{\mathrm{c}}$ \\
10 & $25.74 \pm 2.2^{\mathrm{b}}$ & $10.89 \pm 4.6^{\mathrm{a}}$ & $63.37 \pm 6.5^{\mathrm{c}}$ \\
12 & $80.20 \pm 5.2^{\mathrm{d}}$ & $11.88 \pm 5.6^{\mathrm{a}} \pm 1.7^{\mathrm{b}}$ \\
20 & $10.89 \pm 3.2^{\mathrm{a}}$ & $17.82 \pm 4.1^{\mathrm{a}}$ & $71.29 \pm 8.2^{\mathrm{c}}$ \\
\hline
\end{tabular}




\section{Lipid droplets accumulation in growth phases of $N$. oculata}

Nannochloropsis oculata growing in modified $\mathrm{f} / 2$ medium had no lipid accumulation during the first 14 days of culture. The number of microalgae cells increased however no fluorescence was detected when these cells were stained with Nile Red. At the $20^{\text {th }}$ day of culture, microalgae cells had intracellular lipid droplets since the cells showed fluorescence after stained with Nile Red. The number of cells in cell suspension had fluorescence increased rapidly. Similar, the fluorescence signal of lipid droplets in cell suspension increased gradually from the $20^{\text {th }}$ day to the $35^{\text {th }}$ and $60^{\text {th }}$ day, in both total area and total integrated density (Fig. 3, Table 2). However, there was no change in the number of fluorescent regions in fluorescent cells (table 2). Pluronicgrafted gelatin (PG) was created via urethane linkage between amino groups on gelatin backbone and NPC-remaining moiety of NPC-P-OH. In the PG spectrum, the resonance peak at 7.23-7.29 ppm indicated aromatic protons of phenylalanine and other typical protons of aminoacids in gelatin as noted in Fig. 3. Some protons of the pluronic ($\mathrm{CH}_{3}$ of $\mathrm{PPO}$ at $1.08 \mathrm{ppm}$ and $-\mathrm{CH}_{2}$ of $\mathrm{PEO}$ at 3.6 ppm) also appeared in the spectrum. Moreover, a disappearance of the aromatic proton (NPC) at 7.38-8.22 ppm confirmed the substitution of NPC by the primary amine of gelatin to form $\mathrm{PG}$ copolymer.

Table 2. Lipid accumulation in growth phases of microalgae cells cultured in Erlenmeyer containing modified f/2 medium

\begin{tabular}{|c|c|c|c|c|c|c|}
\hline \multirow{2}{*}{$\begin{array}{l}\text { Time of } \\
\text { culture } \\
\text { (days) }\end{array}$} & \multicolumn{4}{|c|}{ In cell suspension $(334 \times 251 \mu \mathrm{m})$} & \multicolumn{2}{|c|}{ In a fluorescent cell } \\
\hline & $\begin{array}{c}\text { Number } \\
\text { of cells }\end{array}$ & $\begin{array}{l}\text { Number of } \\
\text { fluorescent } \\
\text { cells }\end{array}$ & Total area $\left(\mu \mathrm{m}^{2}\right)$ & $\begin{array}{l}\text { Total integrated } \\
\text { density }\end{array}$ & $\begin{array}{l}\text { Number of } \\
\text { fluorescent } \\
\text { regions }\end{array}$ & Total area $\left(\mu \mathrm{m}^{2}\right)$ \\
\hline 6 & $5 \pm 2^{\mathrm{a}}$ & - & - & - & - & - \\
\hline 10 & $10 \pm 3^{\mathrm{a}}$ & - & - & - & - & - \\
\hline 14 & $15 \pm 5^{\mathrm{a}}$ & - & - & - & - & - \\
\hline 20 & $16 \pm 4^{\mathrm{a}}$ & $4 \pm 2^{\mathrm{a}}$ & $148.9 \pm 44.7^{\mathrm{a}}$ & $139176 \pm 4354^{\mathrm{a}}$ & $1.7 \pm 0.3^{\mathrm{a}}$ & $34.8 \pm 8.0^{\mathrm{a}}$ \\
\hline 35 & $21 \pm 2^{\mathrm{a}}$ & $11 \pm 2^{b}$ & $913.1 \pm 98.4^{b}$ & $1163923 \pm 3399^{b}$ & $1.7 \pm 0.1^{\mathrm{a}}$ & $82.2 \pm 7.9^{b}$ \\
\hline 60 & $40 \pm 0^{\mathrm{b}}$ & $24 \pm 8^{c}$ & $2698.0 \pm 296.3^{\mathrm{a}}$ & $5025762 \pm 4774^{\mathrm{c}}$ & $2.7 \pm 1.3^{\mathrm{a}}$ & $106.6 \pm 12.9^{c}$ \\
\hline
\end{tabular}

The different alphabets following mean in the same column express differences in statistical analysis according to Duncan's test $(\mathrm{p} \leq 0.05)$

(-): no fluorescence was detected
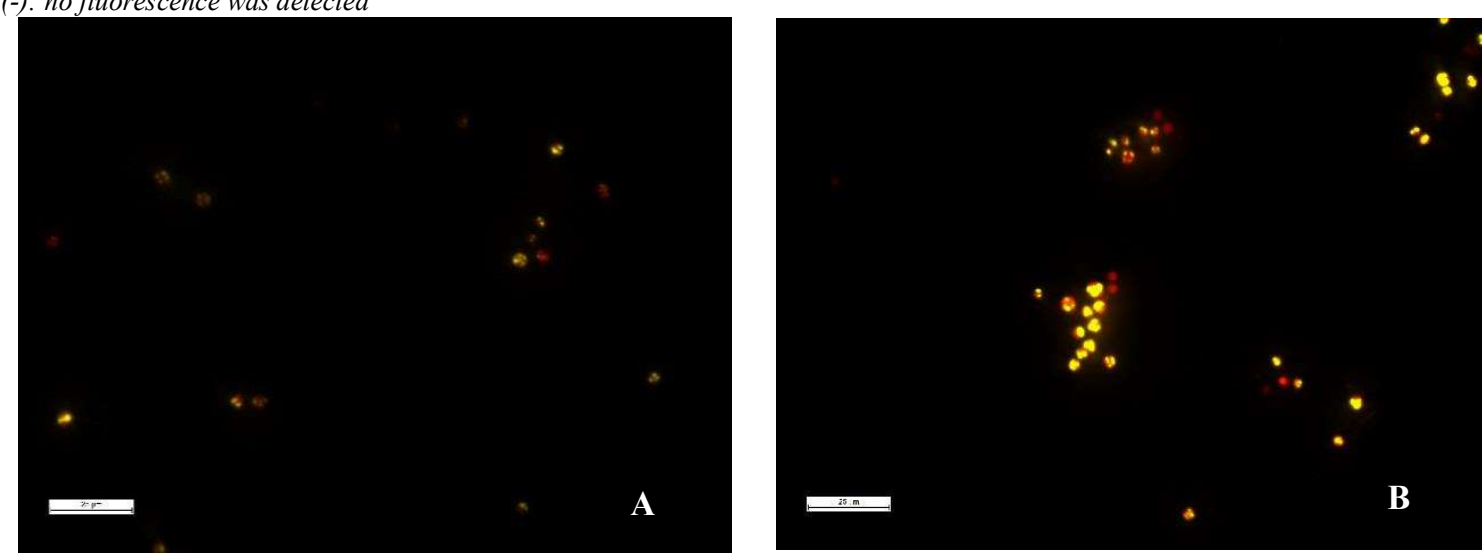

Fig. 3. Fluorescence of the intracellular lipid droplets of Nannochloropsis oculata cultured in Erlenmeyer flasks containing modified f/2 medium after 35 days (A) and 60 days (B). Lipid droplets were stained with Nile Red and left in dark for 15 minutes. Pictures were taken after about 30 seconds exposure to the excitation of $460-480 \mathrm{~nm}$ wavelength and emission of $530-580 \mathrm{~nm}$ wavelength

Effects of nitrogen on growth and lipid time in modified $\mathrm{f} / 2$ medium without nitrogen accumulation of Nannochloropsis oculata cell suspension

The cell density decreased while cell diameter increased when microalgae cell suspensions were cultured in modified $\mathrm{f} / 2$ medium without nitrogen. The cell density greatly decreased as the treatment become longer. In contrast, the cell diameter increased only after two days of culture in nonnitrogen medium. The cells in the treatment with 4-days culture in medium without nitrogen had the widest cell diameter (Table 3). 


\section{CHUYÊN SAN KHOA HỌC TỬ NHIÊN, TậP 2, SỐ 5, 2018}

Lipid droplets were detected (by staining with Nile Red dye) in microalgae cells which were grown in modified $\mathrm{f} / 2$ medium without nitrogen in 2,4 or 6 days of culture. Otherwise, in the control (modified $\mathrm{f} / 2$ medium with nitrogen at $0.88 \mathrm{M}$ ), microalgae cells showed no lipid accumulation. The number of fluorescent cells, total area and total integrated density of fluorescent regions in cell suspensions increased proportionally to the duration of the treatment. In a fluorescent cell, the number of fluorescent regions and total area reached the highest value when the microalgae cells were cultured in non-nitrogen medium for 6 days (Table 4).

Table 3. Cell density and diameter of microalgae cell suspension of Nannochloropsis oculata cultured in Erlenmeyer flask containing modified $\mathrm{f} / 2$ medium with (control) or without nitrogen in 2,4 , or 6 days of culture

\begin{tabular}{|c|c|c|c|c|c|}
\hline \multicolumn{2}{|c|}{ Treatment of nitrogen } & \multicolumn{2}{|c|}{ Cell density $\left(\times 10^{6}\right.$ cells $\left./ \mathrm{mL}\right)$} & \multicolumn{2}{|c|}{ Cell diameter $(\mu \mathrm{m})$} \\
\hline $\begin{array}{l}\text { Concentration of } \\
\text { nitrogen }\end{array}$ & $\begin{array}{l}\text { Time of treatment } \\
\text { (days) }\end{array}$ & After treatment & 10 days & After treatment & 10 days \\
\hline \multirow{4}{*}{ Control } & 0 & $1.0 \pm 0.1^{\mathrm{a}}$ & \multirow{4}{*}{$7.4 \pm 0.1^{\mathrm{b}}$} & $3.1 \pm 0.1^{\mathrm{ab}}$ & \multirow{4}{*}{$3.6 \pm 0.1^{\mathrm{b}}$} \\
\hline & 2 & $2.1 \pm 0.1^{\mathrm{c}}$ & & $2.5 \pm 0.1^{\mathrm{a}}$ & \\
\hline & 4 & $4.0 \pm 0.1^{\mathrm{f}}$ & & $2.8 \pm 0.1^{\mathrm{ab}}$ & \\
\hline & 6 & $5.5 \pm 0.1^{\mathrm{g}}$ & & $3.5 \pm 0.1^{b}$ & \\
\hline \multirow{3}{*}{0} & 2 & $1.7 \pm 0.1^{\mathrm{b}}$ & $7.3 \pm 0.1^{\mathrm{b}}$ & $3.5 \pm 0.1^{\mathrm{b}}$ & $3.5 \pm 0.1^{\mathrm{b}}$ \\
\hline & 4 & $2.6 \pm 0.1^{\mathrm{d}}$ & $7.8 \pm 0.1^{\mathrm{c}}$ & $4.6 \pm 0.2^{\mathrm{c}}$ & $3.4 \pm 0.1^{\mathrm{ab}}$ \\
\hline & 6 & $2.9 \pm 0.1^{\mathrm{e}}$ & $6.9 \pm 0.1^{\mathrm{a}}$ & $3.9 \pm 0.1^{b c}$ & $3.1 \pm 0.1^{\mathrm{a}}$ \\
\hline
\end{tabular}

The different alphabets following mean in the same column express differences in statistical analysis according to Duncan's test $(\mathrm{p} \leq 0.05)$

Table 4. Lipid accumulation of microalgae cells cultured in Erlenmeyer containing modified $\mathrm{f} / 2$ medium with (control) or without nitrogen after 2, 4 or 6 days of culture

\begin{tabular}{|c|c|c|c|c|c|c|c|c|}
\hline \multicolumn{2}{|c|}{ Treatment of nitrogen } & \multicolumn{5}{|c|}{ In observed field $\left(83834 \mu \mathrm{m}^{2}\right)$} & \multicolumn{2}{|c|}{ In a fluorescent cell } \\
\hline $\begin{array}{l}\text { Time of } \\
\text { treatment }\end{array}$ & Concentration & $\begin{array}{l}\text { Number } \\
\text { cells }\end{array}$ & & $\begin{array}{l}\text { Number of } \\
\text { fluorescent } \\
\text { cells }\end{array}$ & $\begin{array}{l}\text { Total area } \\
\left(\mu \mathrm{m}^{2}\right)\end{array}$ & $\begin{array}{l}\text { Total } \\
\text { density }\end{array}$ & $\begin{array}{l}\text { Number of } \\
\text { fluorescent } \\
\text { regions }\end{array}$ & $\begin{array}{l}\text { Total } \\
\text { area }\end{array}$ \\
\hline \multirow{2}{*}{2} & Control & $7 \pm 1^{\mathrm{a}}$ & & - & - & - & - & - \\
\hline & 0 & $8 \pm 1^{\mathrm{a}}$ & & $5.3 \pm 0.1^{\mathrm{a}}$ & $181 \pm 41^{\mathrm{a}}$ & $286359 \pm 17942^{\mathrm{a}}$ & $1.4 \pm 0.2^{\mathrm{a}}$ & $23 \pm 6^{\mathrm{a}}$ \\
\hline \multirow{2}{*}{4} & Control & $14 \pm 2^{\mathrm{c}}$ & & - & - & - & - & - \\
\hline & 0 & $10 \pm 1^{\mathrm{b}}$ & & $7.7 \pm 0.1^{\mathrm{b}}$ & $468 \pm 34^{\mathrm{b}}$ & $720297 \pm 14188^{b}$ & $1.7 \pm 0.1^{\mathrm{a}}$ & $61 \pm 1^{\mathrm{b}}$ \\
\hline \multirow{2}{*}{6} & Control & $18 \pm 1^{\mathrm{d}}$ & & - & - & - & - & - \\
\hline & 0 & $11 \pm 1^{\mathrm{b}}$ & & $9.3 \pm 0.6^{\mathrm{c}}$ & $925 \pm 80^{\mathrm{c}}$ & $1206942 \pm 150795^{\mathrm{c}}$ & $2.2 \pm 0.8^{\mathrm{b}}$ & $99 \pm 5^{\mathrm{c}}$ \\
\hline
\end{tabular}

The different alphabets following mean in the same column express differences in statistical analysis according to Duncan's test $(\mathrm{p} \leq 0.05)$

(-): no fluorescence was detected

According to Halim and Webley (2015), the staining reaction between lipid and Nile Red dye depended on lipid concentration, the ratio of Nile Red dye and lipid as well as the duration of the incubation in darkness [14]. The stronger interaction of lipid and Nile Red dye was, the stronger fluorescence showed. In this experiment, we used the same concentration of Nile Red dye and the incubation time for all samples. Therefore, the integrated density of fluorescent region would represent the concentration of lipid, and the area of fluorescent region would represent the size of intracellular lipid droplet. On the other hand, from these data (number of fluorescent regions, area, integrated density), the accumulation of lipids in microalgae cells could be evaluated. The number of fluorescent regions was the number of lipid droplets in microalgae cell. The area of fluorescent region was the size of lipid droplet and the integrated density of the fluorescent region was the concentration of lipid. 
Growth of cell suspension of Nannochloropsis oculata had two phases of fast growth. In the first fast growth (day $0-6^{\text {th }}$ ), the cell density increased while cell diameter remained steady. In contrast, in the second fast growth (day $8^{\text {th }}-20^{\text {th }}$ ), the cell density and the diameter increased together. The cells got their widest diameter twice during growth (at day $8^{\text {th }}$ and day $20^{\text {th }}$ of culture). The first increase in cell diameter at day 8 occurred just before the second fast growth phase and did not relate to lipid accumulation. Microalgae cells at this phase had no fluorescence when staining with Nile Red dye. The majority of large cells was found in this period and these cells were then divided at the later part of the growth. These results showed that the first growth phase was for biomass accumulation and cell division. And the first increase in cell diameter (day $8^{\text {th }}$ ) was the preparation for the second fast growth which lead to the accumulation of lipids from the $20^{\text {th }}$ day. The cell diameter reached its highest value again at the $20^{\text {th }}$ day while cell density slowly increased. Also, the accumulation of lipids started at the $20^{\text {th }}$ day of culture. At the $20^{\text {th }}$ day of culture, it was difficult to observe the fluorescence of lipid droplets in the cells because they were too small. The accumulation of lipid droplets increased gradually from the $20^{\text {th }}$ day to the $35^{\text {th }}$ and the $60^{\text {th }}$ day, in both size and concentration. However, the number of lipid droplets in microalgae cells did not increase (Table 2).

Nitrogen is one of the factors that have highly impact on the accumulation of lipid in microalgae cells. According to Converti et al., (2009) a 75\% decrease of nitrogen in the medium stimulated lipid accumulation in Nannochloropsis oculata [11]. In our experiments, the treatment of microalgae in non-nitrogen medium promoted the lipid accumulation. Although Nannochloropsis oculata cells grew slowly in nitrogen-depleted medium, intracellular lipid droplets were presented and increased in both size and concentration. While in the control, microalgae cells divided strongly and did not have lipid droplets at that time (Table 4). In particular, nitrogen deficiency in 2 days could rapidly stimulate the accumulation of lipid. The comparison between treatments ( 2 days to 6 days treatments) showed that the longer time of treatment was, the more lipid droplets were accumulated. The number, concentration and size of the intracellular lipid droplets were the highest when microalgae cells were cultivated in nonnitrogen medium for 6 days.

\section{CONCLUSION}

Fluorescence of lipid droplet dyed with Nile Red could be analyzed by using Fiji ImageJ software to fast evaluate the lipid accumulation through numbers, size and concentration of the intracellular lipid droplets of Nannochloropsis oculata. Microalgae cell suspension strongly grew in the first 20 days of culture and started to accumulate lipid droplets from the $20^{\text {th }}$ day and increased lipid accumulation from the $35^{\text {th }}$ day to the $60^{\text {th }}$ day of culture in Erlenmeyer flasks with $20 \mathrm{~mL}$ of modified $\mathrm{f} / 2$ medium. In the lipid accumulation phase (day 35 to day 60 ), the number of lipid droplets was the same while the concentration of lipid increased. In modified $f / 2$ medium without nitrogen, cell density decreased while lipid accumulation increased as soon as nitrogen was depleted.

Acknowledgments: The authors would like to thank to Dr. Thuong Kiet Do for his supports in using Fiji ImageJ software to analyze fluorescent images. This research is funded by Vietnam National University Ho Chi Minh City under grant number C2017-18-02 and Ministry of Education and Training, Vietnam International Education Development (VIED), via Project 911.

\section{REFERENCES}

[1] A. Makri, S. Bellou, M. Birkou, K. Papatrehas, N.P. Dolapsakis, D. Bokas, S. Papanikolaou, and G. Aggelis, "Lipid synthesized by micro algae grown in laboratory and industrial scale bioreactors", Eng. Life Sci., vol. 11, no. 1 , pp. 52-58, 2011.

[2] W. Chen, C. Zhang, L. Song, M. Sommerfeld, and Q. Hu, "A high throughput Nile red method for quantitative measurement of neutral lipids in microalgae", Journal of Microbiological Methods, vol. 77, no. 1, pp. 41-47, 2009.

[3] G.G. Satpati, P.C. Gorain, and R. Pal, "Efficacy of EDTA and Phosphorous on biomass yield and total lipid accumulation in two green microalgae with special emphasis on neutral lipid detection by flow cytometry", Advances in Biology, vol. 2016, Article ID 8712470, 12 pages, 2016, doi:10.1155/2016/8712470

[4] M.D. Abràmoff, P.J. Magalhães, and S.J. Ram, "Image processing with ImageJ", Biophotonics International, vol. 11, no. 7, pp. 36-42, 2004.

[5] J. Cheng, H. Lu, Y. Huang, K. Li, R. Huang, J. Zhou, and $\mathrm{K}$. Cen, "Enhancing growth rate and lipid yield of Chlorella with nuclear irradiation under high salt and $\mathrm{CO}_{2}$ stress", Bioresource Technology, vol. 203, pp. 220-227, 2016. 
[6] T.T.Y. Doan, and J.P. Obbard, "Improved Nile red staining of Nannochloropsis sp", Journal of Applied Phycology, vol. 23, no. 5, pp. 895-901, 2011.

[7] P. Greenspan and S.D. Fowler, "Spectrofluorometric studies of the lipid probe, nile red", Journal of Lipid Research, vol. 26, no. 7, pp. 781-789, 1985.

[8] C. Grove and D.A. Jerram, "jPOR: An ImageJ macro to quantify total optical porosity from blue-stained thin sections", Computers \& Geosciences, vol. 37, no. 11, pp. 1850-1859, 2011

[9] G.H. Huang, G. Chen, and F. Chen, "Rapid screening method for lipid production in alga based on Nile red fluorescence", Biomass and Bioenergy, vol. 33, no. 10, pp. 1386-1392, 2009.

[10] P.D. Kerrison, M.S. Stanley, M. Kelly, A. MacLeod, K.D. Black, and A.D. Hughes, "Optimising the settlement and hatchery culture of Saccharina latissima (Phaeophyta) by manipulation of growth medium and substrate surface condition", Journal of Applied Phycology, vol. 28, no. 2, pp. 1181-1191, 2016.
[11] A. Converti, A.A. Casazza, E.Y. Ortiz, P. Perego, M.D. Borghi, "Effects of temperature and nitrogen concentration on the growth and lipid content of Nannochloropsis oculata and Chlorella vulgaris for biodiesel production", Chemical Engineering and Processing: Process Intensification, vol. 48, no. 6, pp. 1146-1151, 2009.

[12] S.Y. Chiu, C.Y. Kao, M.T. Tsai, S.C. Ong, C.H. Chen, and C.S. Lin, "Lipid accumulation and $\mathrm{CO}_{2}$ utilization of Nannochloropsis oculata in response to $\mathrm{CO}_{2}$ aeration", Bioresource Technology, vol. 100, pp. 833-838, 2009.

[13] R.R.L. Guillard and M.S. Sieracki, Counting cells in cultures with the light microscope. In R.A. Andersen eds. Algal culturing techniques. Elsevier Academic Press, pp. 239-252, 2005.

[14] R. Halim and P.A. Webley, "Nile Red staining for oil determination in microalgal cells: A new insight through statistical modelling", International Journal of Chemical Engineering, vol. 2015, Article ID 695061, 14 pages, 2015, doi:10.1155/2015/695061

\title{
Khảo sát sự tích lũy lipid ở vi tảo Nannochloropsis oculata bằng kỹ thuật phân tích ảnh huỳnh quang
}

\author{
Trịnh Cẩm Tú, Trần Thanh Hương, Bùi Trang Việt \\ Trường Đại học Khoa học Tự nhiên, ĐHQG-HCM \\ Tác giả liên hệ: trthuong@hcmus.edu.vn
}

Ngày nhận bản thảo 12-09-2017; ngày chấp nhận đăng 20-01-2018; ngày đăng 20-11-2018

Tóm tắt-Dịch treo tế bào vi tảo Nannochloropsis oculata được nuôi trong môi trường $\mathrm{f} / 2$ cải tiến nhằm khảo sát sự thay đổi hàm lượng lipid trong tế bào qua các giai đoạn tăng trưởng. Sự tăng trưởng của dịch treo tế bào được xác định thông qua việc đo mật độ và kích thước tế bào dưới kính hiển vi quang học. Thuốc nhuộm huỳnh quang Nile Red được sử dụng để phát hiện và ước lượng hàm lượng lipid trong tế bào vi tảo nhờ kính hiển vi huỳnh quang và phần mềm phân tích ảnh Fiji ImageJ. Mật độ tế bào tăng nhanh và mạnh trong 6 ngày đầu nuôi cấy trong khi kích thước tế bào tăng tối đa ở ngày 8 và ngày 20 . Sự hiện diện của các giọt dầu trong tế bào có thể được nhìn thấy từ ngày 20 của sự nuôi cấy. Kích thước các giọt dầu tăng dần theo thời gian nuôi cấy và đạt cao nhất ở ngày thứ 60 . Xử lý giảm hoàn toàn nitrogen trong môi trường nuôi cấy trong 4 ngày liên tục làm tăng mạnh sự tích lũy giọt lipid trong tế bào. Sự tích lũy lipid trong tế bào theo các giai đoạn tăng trưởng của dịch treo tế bào vi tảo và dưới ảnh hưởng của sự thiếu hụt nitrogen được thảo luận.

Tù khóa-phần mềm Fiji ImageJ, lipid, nuôi cấy vi tảo, Nannochloropsis oculata 